UDC 811.111'367.632

371.3:811.111(438)

$81 ' 243(438)$

\author{
Lech Zabor* \\ University of Wrocław \\ Faculty of Philology \\ Department of English \\ Wrocław, Poland
}

\title{
PERCEPTION OF UNIQUENESS AND THE ACQUISITION OF THE ENGLISH ARTICLE SYSTEM
}

\begin{abstract}
This paper examines the patterns of article use by Polish learners of English as a second language. On the basis of existing theories of the meaning of English articles, it will be demonstrated that the acquisition of the English article system depends on learners' perception of the uniqueness of a noun phrase. The purpose of the article is to compare learners' performance in the forced-choice elicitation task in three categories of noun phrases: (1) definite and unique through associations, (2) definite and unique through previous mention, general knowledge or knowledge of the immediate situation), and (3) indefinite and unique through associations or previous mention. The analysis of data obtained from two groups of lowerintermediate and advanced learners leads to certain limited conclusions about the role of uniqueness and other semantic and discourse-related universals that contribute crucially to the interpretation of the English definite article.
\end{abstract}

Key words: acquisition of English articles, definiteness, uniqueness

E-mail address for correspondence: 1.r.zabor@uni.wroc.pl 


\section{Introduction}

English articles can be referred to as a relatively simple, closed system of generally unstressed morphemes, which encode such complex semantic notions as existence, reference and attribution; discourse notions of context and anaphora and syntactic notions of number and countability (BurtonRoberts 1976). In consequence, the articles are one of the most difficult structural elements for second language (L2) learners.

The acquisition of English articles by learners from different first language (L1) backgrounds has been an area of considerable interest in second language acquisition research (SLA) in the past three decades. Early studies of morpheme acquisition orders in English, such as e.g. Oller and Redding (1971) and Larsen-Freeman (1975), show that the accuracy of article use was lower for speakers of article-less languages like Japanese, Chinese and Korean than for other learners who had articles in their L1s (French, Spanish and German). Similarly, Duškova (1969) claims that the difficulty experienced by Czech learners in mastering the English article system is due to the absence of articles in Czech. A series of comparative studied by Ringbom (1985) have confirmed that learners' problems appear to be more serious when their native languages do not have articles or article-like morphemes. Huebner (1983) and Thomas (1989) have shown that article misuse in the acquisition of English as a second language is not random, but is connected to language and discourse universals, which determine interpretation of the target determiner phrase (see Bickerton 1981).

More recently, various positions have been proposed by researchers in the generative second language acquisition field as to whether L2 learners transfer their L1 grammar at the initial state of SLA and whether they have full access to Universal Grammar (UG), including new parameter settings. The underlying assumption of the majority of those positions is that L2 interlanguage (IL) grammars are UG-constrained (see, e.g. Hawkins 2005, Ionin, Ko and Wexler 2004, Goad and White 2004, Prévost and White 2000 and Trenkic 2007, inter alia).

The major findings of those studies demonstrate that speakers of L1 article-less languages differ from native speakers of English in at least three ways: (1) they drop articles where $a /$ the is obligatory for native speakers (omission errors), (2) they use the where $a$ is required and vice versa (commission errors), and (3) they may overgeneralize the in contexts 
where no article is necessary in English (flooding errors). This paper is an attempt to investigate the process of article acquisition in L2 English by speakers of Polish in terms of learners' perception of noun phrase uniqueness, familiarity and other related semantic universals.

\section{Uniqueness and the definite article}

\subsection{Early accounts of uniqueness}

Studies of the meaning of the English articles have been approached from two broad perspectives, which can be characterized as 'uniqueness' and 'familiarity'. Researchers such as Russell (1905) and Hawkins $(1978,1991)$ claim that felicitous use of the definite article requires that the NP referent be uniquely identifiable to the hearer, whereas Christophersen (1939), Strawson (1950) and Heim (1982), inter alia, argue that the definite referent of the NP must be familiar within the discourse.

Early accounts of uniqueness in definite noun phrases were based on Russell's (1905) Theory of Definite Descriptions. To illustrate the main assumptions of this theory let us first analyze the following sentences (from Hawkins 1991:406-407).

(1) The professor is drunk

(2) A professor is drunk.

The logical translation of (1) can be represented as (3), symbolizing professor by $\mathrm{P}$ and drunk by $\mathrm{D}$ :

(3) $\exists \mathrm{x}(\mathrm{P}(\mathrm{x}) \& \sim \exists \mathrm{y}(\mathrm{P}(\mathrm{y}) \& \mathrm{x} \neq \mathrm{y}) \& \mathrm{D}(\mathrm{x}))$

i.e. there is an $\mathrm{x}$ who is a professor, and there is no $\mathrm{y}$ such that $\mathrm{y}$ is a professor and non-identical to $\mathrm{x}$, and $\mathrm{x}$ is drunk.

This analysis implies the three components of the utterance:

A. Existence: There is a professor.

B. Uniqueness: There is only one professor.

C. Predication: This individual is drunk. 
The first two propositions - the existential clause and the uniqueness clause characterize the definite description of the NP in question and are assumed to be the crucial elements in Russell's formal analysis of definite noun phrases. If we compare (1) and (2), the major difference between them lies in its uniqueness claim: (2) may be logically represented as (4)

(4) $\exists \mathrm{x}(\mathrm{P}(\mathrm{x}) \& \mathrm{D}(\mathrm{x})$

i.e. there is an $\mathrm{x}$ who is a professor, and $\mathrm{x}$ is drunk

Similarly, sentence (5) signals that there is just one entity satisfying the description used. The most natural interpretation of (6) is that only one car is involved, but the possibility is left open that Mary may have just bought more than one car.

(5) Mary's gone for a ride in a car she just bought.

(6) Mary's gone for a ride in the car she just bought.

This leads to the obvious conclusion that the indefinite article $a$ in its nongeneric meaning does not signal uniqueness, but as in the examples above show, it does not signal non-uniqueness either.

\subsection{Ways of expressing uniqueness}

More recently Hawkins (1978) in a study of definiteness and indefiniteness identified a number of non-generic uses of the definite article related to the identifiability and uniqueness of a referent in discourse. Some of the ways of establishing uniqueness are presented below.
A. [Anaphorically - Through previous mention]
I bought a blue cup. The blue cup broke.
B. [Through associations]
We went to a wedding. The bride was very tall.
C. [Through entailment, via PPs, adjectives or modifying clauses] The roof of our house is leaking.
D. [Through world knowledge] The sun is shining.
E. [In the visible situation] Pass me the salt, please. 
In this paper we concentrate on the type of uniqueness that is indicated through associations in the discourse context. This is not expressed directly through anaphora, nor is it signaled by such grammatical devices as prepositional phrases (PPs) or modifying clauses. Hawkins (1978) claims that the term "association" cannot be described with satisfactory accuracy, yet we can adequately define the difference between general and specific knowledge uses of the definite article with reference to associative and purely anaphoric types of definite NPs. He writes:

\begin{abstract}
A general knowledge use of the definite article will be one which is made possible on the basis of an associative relationship between the generic expressions which correspond to the specific trigger and its associates. Thus, the generics corresponding to $a$ wedding: the bride will be weddings have brides, or a wedding has a bride. (...) On the other hand, specific knowledge of a referent is knowledge which cannot be inferred about a car or a wedding, etc.

Hawkins (1978:124-125)
\end{abstract}

This means that non-associative, or as Hawkins writes, "strict" anaphora, is not possible on the basis of general knowledge of the entity within a class of entities. The two types of definite article use based on general and specific knowledge of the NP referent constitute the main dichotomy in the interpretation of the definite noun phrases in which uniqueness is expressed through associations or previous mention anaphora. In the following section we briefly outline the ways of expressing uniqueness relevant to the present study.

\title{
2.3. Uniqueness through associations
}

The associative use in the computation of uniqueness of the NP referent seems quite problematic because the hearer must know the entity in question, its nature and, for example, its cultural context. In a sentence such as The bride was very tall the hearer knows that weddings involve brides, but also grooms, guests, wedding cakes, etc. He should be able to make the natural inference that the reference is to the bride at the particular wedding (there is usually one bride at a wedding) although he may not know anything about her. Lyons (1999) refers to this type of associative 
uses as bridging cross-reference. He describes them as a combination of the anaphoric and the general knowledge types. Similarly, in (7) the NP referent in the second sentence (the driver) has not been mentioned before, but there has been mention of the entity connected with the definite NP in question, that is a taxi.

(7) I had to get a taxi from the station. On the way the driver told me there was a bus strike.

It is part of our knowledge that taxis have drivers as well as wheels, seats, fares, etc. and any of them can be referred to by means of a definite noun phrase. So the referent the driver is uniquely identifiable through association with the antecedent a taxi. The italicized NP in (7) represents an entity that is new to the discourse, yet its existence is easily accommodated on the basis of the evoked trigger taxi. That is, we can easily infer the likely existence of a driver, and in this case we can infer its uniqueness. The criterion of uniqueness is particularly significant in cases where the referent is hypothetical or in the future. In (8) we may assume that the competition is not yet over and the winner is definitely not identifiable, but he or she is unique in that a single winner is implied.

(8) The winner of this competition will get a week in the Bahamas for two.

Lyons (1999) claims that many situational uses are also associative. A definite NP is possible because the speaker and the hearer take it for granted that some situations involve certain entities. Even though the speaker cannot identify the NP referent and he does not expect the hearer to be able to do so, they both know that there is such an entity in the situation. The following examples come from Lyons (1999:9).

(9) [Nurse entering operating theatre] I wonder who the anaesthetist is today.

(10) I wonder who that anaesthetist is.

In (10) the speaker does not know the identity of the person referred to, but she is referring to a particular individual, which means that demonstratives may require identifiability but definites do not (op. cit.). 


\subsection{Uniqueness and inclusiveness}

The parameters of uniqueness may also be defined on the basis of a more general kind of knowledge of associative relationships between entities, such as the fact that any set of elements will have a unique entity, which sanctions a first-mention the in the sentence Who is the professor? when students arrive for a new class. This regularity is labelled inclusiveness (Hawkins 1978). Examples of such associative relationships between a set and its elements include, for example:

- a class $\rightarrow$ the professor, the textbook, the final exam

- a wedding $\rightarrow$ the bride, the bridesmaids, the cake

- a house $\rightarrow$ the roof, the attic, the walls

- a car $\rightarrow$ the steering wheel, the engine, the dashboard

- a murder $\rightarrow$ the victim, the killer, the knife

To illustrate this notion let us analyze the inclusiveness effect in (11). Here the uniqueness involves a relationship of the definite NP and its antecedent, so the hearer may assume that there is a single dashboard in the car in question, the same as there is a single bride at the wedding, but not only one dashboard in the entire world.

(11) This car has a statue on the dashboard.

Roberts (2003) claims that many NPs are susceptible to such interpretation. He writes that 'the head is interpreted as a relation such as dashboard of, with an implicit argument contextually given, e.g. the denotation of the salient and relevant this car" (op. cit.:290). The interpretation of the definite NP is on pragmatic grounds, since the hearer knows that there is more than one dashboard in the world but there is generally only one per car. Roberts (2003) asserts that the phrase 'dashboard of' denotes not just a relation, but also a function which constitutes the uniqueness effect.

As was shown in the above examples, bridging cross-reference and inclusiveness generally involve the interlocutors' common knowledge of the entities in context. When this knowledge is not absolutely entailed, the definite NP referent may or may not be relevant to what comes before. In order to make the last sentence in (12) relevant we need to establish that 
John was killed by shooting, and not, for example by poisoning, stabbing or strangling. This will entail the existence of a gun as the possible murder weapon, otherwise the use of the definite article in the noun phrase may not be justified, as in (14). The examples below are based on Roberts (2003:300).

(12) John was murdered yesterday. ?The gun lay nearby.

(13) John was shot yesterday. The gun lay nearby.

(14) \#John was stabbed yesterday. The gun lay nearby.

It is interesting to note that the antecedent connected with the NP referent may not even occur in the preceding sentence, or part of the sentence. The felicity of (15) requires no such trigger on the basis of which the hearer can infer the existence of the plane in question.

(15) They've just got in from New York. The plane was five hours late.

The associative use of the definite referent is based on the hearer's world knowledge that an aircraft is the most likely form of conveyance to travel from New York to most places and making the inference that the reference is to the particular plane. As the above utterance shows, the definite article may be felicitously used to denote entities which are included, for instance, in the global context of travelling, but they have not been previously mentioned in the discourse.

Similarly, Roberts (2003) in a recent study of definite noun phrases analyses a type of uniqueness, which he refers to as informational uniqueness. In some situations, the hearer may reasonably assume that there is only one entity in the context even though there is no antecedent in the preceding sentence. Roberts claims, for example, that in (16) a child is justified in assuming that there is only a single clown in the puzzle in question and also, only a single puzzle on the next page.

(16) [Teacher giving directions] On the next page you will find a puzzle.

Find the clown in the puzzle. 


\subsection{Absolute uniqueness}

All the examples discussed above involve the idea of uniqueness, i.e. the definite article signals that there is only one entity that refers to the NP referent in the particular situation. Uniqueness established through associations or anaphora is not usually absolute, but rather relative to a particular context. Thus, in (8) there is just one winner of the competition and in (9) it is assumed that there is one anaesthetist taking part in the operation. However, the uniqueness of the definite article can also be absolute when the NP referent is 'inherently unique'; that is, it denotes something of which there is only one entity, e.g. the sun, the moon, or the universe (Lyons 1999:8). We do not normally speak of $a$ sun or a universe because we think of our sun in the solar system, although we know that there are millions of suns in the universe or perhaps there is a possibility of there existing another parallel universe(s). Similarly, nouns like Pope, king, queen or president are often considered to be inherently unique, because there is usually one at a given time in a given situation, although there have been many Popes in history, and at present there are many kings or presidents (but generally not in one country), thus from this perspective we may speak of a Pope or a president. Hawkins (1991:421) presents the following examples which refer to the two possible interpretations of the definite and indefinite articles, and offers the following explanation for them.

(17) England has a prime minister, and America has a president.

(18) England has the prime minister, and America has the president.

Sentence (17) defines certain state officials in England and America while (18) allows an interpretation that England has the prime minister of some other country currently on a state visit, England has the prime minister that somebody was just talking about or England has John Major and America has George Bush. Lyons (1999) concludes that one can always find a context in which a noun may not be unique, yet it does not invalidate the point. It seems that this way of expressing uniqueness is quite transparent for L2 learners of English as they share the same general knowledge of the world and its unique elements with native speakers of English. Another reason is that such inherently unique NPs are frequently available in the input. 


\subsection{Definiteness without uniqueness}

Finally, as we have stated before, the two dominant views of definiteness, i.e. uniqueness and familiarity can account for the vast majority of felicitous uses of the definite article in English, however they cannot account for all. A unique but unfamiliar entity may be felicitously referred to with the definite article, while a familiar but non-unique referent may also be felicitously interpreted as a definite NP. The following examples from Birner and Ward (1994:93) illustrate the point.

(19) If you're going into the bedroom, would you mind bringing back the big bag of potato chips that I left on the bed?

(20) [Hotel concierge to guest] You're in Room 611. Take the elevator to the sixth floor and turn left.

The bag of potato chips in (19) is unfamiliar information and the entity is not uniquely identified by the NP, as there could be several such bags in the room. However, as long as it is assumed by the speaker to be the only bag of chips left on the bed, the referent is uniquely identifiable. In (20), on the other hand, no unique elevator is inferred in the given context, yet the use of the definite article is perfectly acceptable. Whenever the referent is not uniquely identifiable on the basis of the definite NP it must be undifferentiated in context, that is the elevators in this case are undifferentiated with respect to the purpose of use, so the hotel guest can take any of them to get to the sixth floor. This means that such cases do not involve any antecedent or trigger on the basis of which the hearer is expected to infer a unique elevator. As Birner and Ward explain, in the absence of uniqueness the definite article is used, for example, for those conveyances or entities that move along a regular, pre-established path or occur in usual contexts as in (21), but not in (22).

(21) To get to the railway station, I suggest taking the bus.

(22) \#To get to the railway station, I suggest taking the taxi.

It seems that the felicity of an utterance is crucially dependent upon the beliefs of the interlocutors concerning the relevance of unique identification of the particular entity. Sentence (23) refers to a uniquely identifiable bank, while (24) may not. 
(23) Mr. Johnson robbed the bank.

(24) Mr. Johnson went to the bank.

On the basis of such utterances Birner and Ward (1994) conclude that neither familiarity within the discourse or within the hearer's knowledge nor uniqueness, i.e. the property of being uniquely identifiable to the hearer, is a necessary condition for the felicitous use of the definite article. Yet, they claim that uniqueness is sufficient for the correct use of the definite article. In the following section we discuss the study based on the notion of uniqueness as the underlying semantic universal in the correct choice of L2 English articles.

\section{The study}

\subsection{Research questions and hypotheses}

In this research, we concentrate on the associative and anaphoric use of the definite article in L2 English. Following the proposal of Birner and Ward (1994) that uniqueness is a sufficient condition for the felicitous use of the definite article, we hypothesize that L2 English learners are able to access the semantic universal of uniqueness, but their perception of this feature will depend on (1) the ways in which it is expressed in the utterance, and (2) the learners' level of L2 English proficiency. In particular, we refer to the two ways of establishing uniqueness, i.e. (I) through associations, and (II) through previous mention, general knowledge and the knowledge of the situation.

\section{Hypothesis 1}

L2 English learners will choose the definite or indefinite article when uniqueness is established in the discourse context through associations. The degree of fluctuation will depend on the level of students' proficiency in English

\section{Hypothesis 2}

L2 English learners will choose the definite article when uniqueness is established in the discourse context through world 
knowledge, in the visible or immediate situation or anaphorically, through previous mention.

Additionally we intended to investigate the use of the indefinite article in the noun phrases related to the antecedent through association and previous mention without uniqueness. We further hypothesize that learners may have difficulty establishing definiteness of a NP in a variety of discourse contexts that do not entail uniqueness of the referent in question. This leads to hypotheses 3.

\section{Hypothesis 3}

English learners will choose the definite and indefinite article to mark a definite non-unique NP referent related to the antecedent that has been previously mentioned in the discourse, or is related to the antecedent in the preceding sentence or part of the sentence.

\subsection{Participants and procedure}

The participants in this study were 80 L1 Polish learners of L2 English. They were recruited from university-level graduate students of English, Polish and history and students of three local secondary schools. The Oxford Placement Test (Allan 2004) was used to assess their proficiency in English. On the basis of these results, the participants were divided into low and high proficiency groups. The lower-intermediate group consisted of 23 female and 17 male students between 16 and 18 years of age. The advanced group comprised 40 MA level students of English, Polish and history (29 females and 11 males), between the ages of 21 and 25. A control group of native speakers of English also participated in the study. It consisted of 12 native speakers of British and American English employed mostly as lecturers and teachers at Wrocław University, the local schools and colleges and a few engineers and lawyers working for local business companies and financial institutions. No beginner group was included as it was doubtful whether they would be able to handle the experimental task.

Testing took place in the premises of Wrocław University and the secondary schools in the classroom setting for all learners. The native 
speakers were interviewed in their offices, at the university or in the schools they worked for. The secondary school participants were not informed about the purpose of the study as the tasks were part of their end-of-semester school progress test. Similarly, the university students were asked to perform a number of written tasks as part of the MA course requirement, however at the time of the research they were not acquainted with details of the experiment.

\subsection{Task}

A forced-choice elicitation task was used in the study. The test was similar in design to other instruments employed in previous studies of the acquisition of L2-English articles, e.g. Ionin, Ko and Wexler (2004). It consisted of 40 short sentences or dialogues mostly based upon the examples adapted from Hawkins $(1978,1991)$, Lyons (1999), Birner and Ward (1994), Roberts (2003) and Ionin, Ko and Wexler (2004). Several dialogues and distractor sentences were designed by the author and two native speakers of the control group. Out of the total number of 40 tokens, 30 were coded as relevant to the experiment while the remaining 10 were beyond the scope of the present study. They were not the subject of analysis as they required, for example, the use of the zero article in article-less NPs, and for that reason they were included in the study. Otherwise the learners might have focused entirely on the suppliance of the/ $a$ and ignore the null article. Examples of such items are presented below.

(25) [Passenger at the airport] Excuse me, have you seen a redhaired girl? She is my daughter. I think she flew in on flight 239 , but I'm not sure.

(26) Jane had a terrible accident, she's in hospital now.

(27) He was elected member of parliament for Oxford.

The sentences and dialogues contained three NP categories, two definite (one unique through association and one unique through previous mention, world knowledge or the knowledge in the visible/immediate situation) and one indefinite (non-unique through association or previous mention). Each context was tested in ten coded noun phrases, where one 
choice had to be provided (the $a / a n$, or $\varnothing$ ). The distribution of categories in the test was as follows:

Context 1 [unique through association]

Context 2 [unique through previous mention]

Context 3 [non-unique]

Context 4 [other, un-coded]
10 tokens

10 tokens

10 tokens

10 tokens

The test items were carefully selected so most of the target NPs were singular and in the subject or direct/indirect object position. Also, the test was checked by the native speakers and two secondary school teachers to make sure that all the examples would be fully understood by the participants. The native speakers were asked to supply the missing articles in the dialogues, and they performed as expected. However, there were a few problematic cases in which the majority of the respondents suggested that both the indefinite article and the definite article could be used, as in (28). Such examples were left un-coded, or removed from the test.

(28) [Woman] What's wrong with Bill?

[Man] Oh, the/a girl he went out with was nasty to him.

Also, one of the non-teacher respondents argued for the two articles in the majority of definite noun phrases giving examples of contexts in which a non-unique NPs was, in his view, equally or more natural. For example, in the part of the USA where he lived most people used to keep more than one dog, so he insisted the preferred form in (29) would be $a$ instead of the.

(29) Don't go in that yard, the/a dog will bite you.

However, the rest of the respondents unanimously accepted the in (29) as the most likely choice in this context, so the test item was kept and coded for further analysis. 


\section{Results and discussion}

As predicted, the lower-intermediate learners were less accurate in their article use across all categories than the more proficient learners. The overall score for all the contexts was 47.75 percent of correct answers in comparison to 84.92 percent in the advanced group. Article omission was relatively low in all categories, which shows that the lack of accuracy observed in the learners' performance on the task was mainly due to article misuse. Omission of articles was evidently higher in the lower-intermediate group, 11.67 percent in all contexts in comparison to 4.17 percent in the advanced group. This observation corresponds with the previous studies which have revealed high article omission at lower levels of learners L2 English proficiency (see e.g. Hawkins et al. 2006).

The results of the study are summarized in Table 1, which shows the percentage of correct/incorrect choices and omission of articles in the three categories. The results corresponding to the target response for each category are highlighted.

\begin{tabular}{|l|ccc|ccc|}
\hline & \multicolumn{2}{|c|}{$\begin{array}{c}\text { Group 1 } \\
\text { (lower-intermediate) } \\
\text { (N=40) }\end{array}$} & \multicolumn{3}{|c|}{$\begin{array}{c}\text { Group 2 } \\
\text { (advanced) } \\
\text { (N=40) }\end{array}$} \\
\hline Category & a & the & $\varnothing$ & a & the & $\varnothing$ \\
\hline $\begin{array}{l}\text { 1. } \text { unique through } \\
\text { association with or } \\
\text { without the antecedent } \\
\text { (target: the) }\end{array}$ & 46.75 & 39.50 & 13.75 & 7.75 & $\mathbf{8 5 . 5 0}$ & 6.75 \\
\hline $\begin{array}{l}\text { 2. unique through } \\
\text { previous mention, world } \\
\text { knowledge or in the } \\
\text { visible situation } \\
\text { (target: } \text { the) }\end{array}$ & 33.00 & 57.75 & 9.25 & 11.00 & $\mathbf{8 6 . 0 0}$ & 3.00 \\
\hline $\begin{array}{l}\text { 3. non-unique with } \\
\text { association or previous } \\
\text { mention (target: } a \text { ) }\end{array}$ & 46.00 & 43.50 & 10.50 & $\mathbf{8 3 . 2 5}$ & 14.00 & 2.75 \\
\hline
\end{tabular}

Table 1. Results of the forced-choice elicitation task in both groups. 
The data reported in this section provide support for the proposed hypotheses. The Polish L2 English learners were sensitive to the semantic concept of uniqueness and used it to determine the definiteness of a noun phrase. However, they differed in their perception of the ways of establishing uniqueness. The lower-intermediate students over-relied on the discourserelated factors such as previous mention and the more transparent means of expressing uniqueness based on the general knowledge of the world (e.g. the sun, the sky), or in the immediate situation where the definite referent was physically present (e.g. the dog, the salt). The percentage of correct answers in this NP category was about 58 in this group, whereas the number of target-like choices in category 1 (uniqueness through association) did not exceed 40 percent. The students had visible problems with the correct interpretation of the definite noun phrases, regardless of the fact that they occurred with the antecedent (e.g. a wedding - the bride, a taxi - the driver), and only few definite referents (e.g. the plane) were not preceded by the directly expressed corresponding noun phrases (e.g. They've just returned from New York. The plane was five hours late.) Also, in context 3 (uniqueness without previous mention or association) the pattern of learners' article choice revealed a great deal of fluctuation between the definite and the indefinite article, with the number of correct and incorrect answers almost equally distributed (43.5 percent vs. 46 percent respectively).

In the advanced group, a statistically significant difference in the students' performance in article choice in categories 1 and 2 was not recorded. In fact, they did slightly better in selecting the definite article for the NPs based on uniqueness established through associations than through anaphora or general knowledge ( 86 and 85.5 percent respectively). Unlike the findings from the low intermediate group, the advanced learners showed a considerably smaller difference between the accurate use of the definite article in the three contexts. This evidence seems to support the underlying assumption of the study that L2 English learners fluctuate in their choices of the definite and indefinite article in relation to their perception of uniqueness in L2, and this period of optionality gradually disappears with the learners' increasing proficiency in the second language.

A within-group analysis of students' performance in the three contexts shows a relatively high correlation between the scores of category 1 and 2 for both groups ( $r=.76$ in group 1 and $r=.56$ in group 2) and category 1 and 3 in the advanced group $(r=.57)$. The correlation coefficient for 
the scores in category 2 and 3 in both groups and category 1 and 3 in the lower-intermediate group was close to zero or mildly negative. This reveals relatively high variability in the students' interpretation of definite and indefinite unique noun phrases in context 2 and 3, in which the referent in the second mention was frequently preceded by the definite article no matter whether it was definite or indefinite. The following table presents Pearson's correlation analysis of the students' raw scores in the three categories.

\begin{tabular}{|r|cc|cc|}
\hline & \multicolumn{2}{|c|}{ GROUP 1 } & \multicolumn{2}{|c|}{$\begin{array}{c}\text { GROUP 2 } \\
\text { (advanced) } \\
\text { Category 2 }\end{array}$} \\
& Category 3 & Category 2 Category 3 \\
\hline GROUP 1 - Category 1 & $.76^{*}$ & -.01 & - & - \\
Category 2 & - & -.15 & - & - \\
\hline GROUP 2 - Category 1 & - & - &. $\mathbf{5 6 *}$ & $\mathbf{. 5 7 *}$ \\
Category 2 & - & - & - & .07 \\
\hline
\end{tabular}

*Correlation significant at $\mathrm{p}<.001$

Table 2. In-group correlation analysis of the three categories of NPs.

Closer scrutiny of the responses provided by the learners shows a possible influence of a number of factors which may have affected their interpretation of the uniqueness of a NP. The question is what makes a strong or a weak cue of uniqueness in L2 English for speakers of article-less languages; previous mention, association, world knowledge or perhaps the entailment expressed, for instance, through the grammatical structure of possession (e.g. the roof of my house). We assume that the weakest indication of uniqueness is through association because it is the least salient as the relationship between the definite referent and its antecedent or the context situation is not expressed syntactically. On the other hand, in the case of unique NPs expressed through entailment learners need to understand the structure and the meaning of prepositional phrases such as the genitive of, modifying clauses and adjectives like the best, etc. In spite of their syntactic complexity, those ways of establishing the uniqueness of a noun phrase are quite transparent and they mostly refer to relatively 
invariant forms. This means that we very rarely hear phrases like a roof of my house, since houses hardly ever have more than one roof.

This observation leads to the conclusion that exposure to L2 input and availability of a particular NP in the input accelerates the acquisition of the articles in L2 English. We may predict that learners will acquire first those NPs in which uniqueness is signaled by easily available, reliable cues that always map the same form onto the same meaning or function, the sun always refers to 'our' sun and the roof of my house always refers to the same unique, definite entity. (The notion of 'form-function mapping' was proposed by MacWhinney (2001) in his Competition Model, according to which the learner discovers which forms are used to realize which functions, and what 'weights' to attach to individual forms in the performance of specific functions).

Another factor that may have influenced the learners' article choice is formal instruction provided in the form of overt pedagogical rules. It is an established practice in Polish schools that learners are taught how to use English articles through formal instruction based upon such rules as 'first-mention vs. second- mention'. Thus, learners are instructed to use the indefinite article with noun phrases that occur for the first time in the discourse and the definite article with those noun phrases that have been mentioned before. The problem is that the rule works pretty well in most contexts, as in (30), where uniqueness is established through anaphora, but not, for example, with indefinite, specific NPs which are part of a larger set of elements as in (31). The NPs in (30) and (31) were both interpreted as definite by many low proficient learners because they occurred for the second time in the discourse.

(30) I bought a blue cup. The cup broke.

(31) The pet shop had five puppies and seven kittens. Mary chose $a$ puppy.

The NP property in (31) is defined as a type of presuppositionality, referred to as partitivity (see, e.g. Heim 1982). This semantic notion is established for indefinites by introducing in the previous discourse a set that the target NP belongs to. Partitivity, or 'being one of', is often expressed directly by means of the phrase one of the instead of the indefinite article $a$, as in (32), or in (34). 
Lech Zabor Perception of uniqueness and the acquisition of the English article system

(32) The pet shop had five puppies and seven kittens. Mary chose one of the puppies.

(33) We went to a wedding last week. A guest made a speech.

(34) We went to a wedding last week. One of the guests made a speech.

We may suppose that the infelicitous article choices made by the lower-intermediate learners in context 1 and 3 was caused by their inability to interpret the NP in question as unique or non-unique. A high percentage of incorrect article choices in the first-mention, definite, unique NPs and in the second mention indefinite, unique NPs could have resulted from the learners' mechanical responses to the position of the referent in the discourse. The learners may have been motivated by the explicit, pedagogical rule, according to which new NPs, mentioned for the first time in the discourse are by definition indefinite, while previously mentioned NPs are always definite.

\section{Conclusion}

Regarding the research hypotheses, which predicted fluctuation in the use of the and $a$ in contexts 1 and 3 as well as higher accuracy of article choice in context 2, we may conclude that the analysis of the learners' accuracy across the tasks largely confirms the predicted patterns of article commission. However, the available data also suggest that L2 English article choice involves the optional use of the definite and indefinite forms of articles as it is also characterized by a certain amount of variability in the context in which fluctuation was not expected.

The assumption of this study was that any difference between the performance of the two groups of learners would be due to their different proficiency levels; the advanced learners were expected to be more accurate in their article choice in L2 English since they were less affected by such factors as specificity and were able to distinguish between definite and indefinite contexts. Although the results in the advanced group proved to be significantly better, still they were far from the target-like pattern of article selection. A detailed in-group analysis shows that the advanced learners also manifested some difficulties in matching definiteness and uniqueness with their grammatical representations. 
We think that the possible explanation of the optional patterns of article use may primarily concern the factors which have been already discussed: the perception of uniqueness, the learners' L2 proficiency, exposure to L2 input and the role of formal instruction in elicitation tasks. As regards the methodology of the research, the present study investigated the performance of subjects in the L1 setting, on the basis of a single data collection technique, that is, a forced-choice elicitation task. It seems that article misuse and omission may be even greater in spontaneous language use. Learners may be able to supply articles in obligatory contexts as a result of explicit teaching rather than the presence of those morphological features at a deeper level of their IL grammars. Studies of English article acquisition (e.g. Robertson 2000) show that in more spontaneous, uncontrolled forms of L2 use, such as oral production, formal instruction and explicit pedagogical rules have little, if any effect on the learners' choice of articles. Therefore, in order to obtain a more complete picture of the L2 acquisition of the English article system, we need data based on both recognition and production.

\section{References}

Allan, D. (2004). Oxford Placement Test 1. Oxford: OUP.

Bickerton, D. (1981). Roots of Language. Arbor, MI: Karoma Press.

Birner, B. and G. Ward (1994). Uniqueness, Familiarity and the Definite Article in English. Proceedings of the Annual Meeting of the Berkeley Linguistic Society, No 20, 93-102.

Burton-Roberts, N. (1976). On the Generic Indefinite Article. Language, $52,2,427-448$.

Christophersen, P. (1939). The Articles. A Study of Their Theory and Use in English. Copenhagen: Munksgaard.

Duškova, L. (1969). On Sources of Errors in Foreign Language Learning. IRAL, 7, 11-36.

Goad, H. and L. White (2004). Ultimate Attainment of L2 Inflections: Effects of L1 Prosodic Structure. In: S. Foster-Cohen, M. Sharwood Smith, A. Sorace and M. Ota (eds.), EUROSLA Yearbook 2004 (Vol 4), Amsterdam: John Benjamins, 119-145.

Hawkins, J. A. (1978). Definiteness and Indefiniteness. A Study in Reference and Grammaticality Prediction. London: Croom Helm. 
Hawkins, J. A. (1991). On (In)Definite Articles: Implicatures and Grammaticality Prediction. Journal of Linguistics, 27, 405-42.

Hawkins, R. (2005). Explaining Full and Partial Success in the Acquisition of Second Language Grammatical Properties. Second Language, 4, 725.

Hawkins, R., S. Al-Eid, I. Almahboob, P. Athanasopoulos, R. Chaengchenkit, J. Hu, M. Rezai, C. Jaensch, Y. Jeon, A. Jiang, Y. I. Leung, K. Matsunaga, M. Ortega, G. Sarko, N. Snape and K. Velasco-Zárate (2006). Accounting for English article interpretation by L2 speakers. In: S. Foster-Cohen, M. Medved Krajnovic and J. Mihaljevic Djigunovic (eds.), EUROSLA Yearbook 2006, Amsterdam: John Benjamins, 7-25.

Heim, I. (1982). The Semantics of Definite and Indefinite Noun Phrases. Doctoral dissertation, Amherst, MA: University of Massachusetts.

Huebner, T. (1983). A Longitudinal Analysis of the Acquisition of English. Ann Arbor, MI: Karoma Press.

Ionin, T., H. Ko and K. Wexler (2004). Article Semantics in L2 Acquisition: The Role of Specificity. Language Acquisition, 12, 3-69.

Larsen-Freeman, D. (1975). The Acquisition of Grammatical Morphemes by Adult ESL Students. TESOL Quarterly, 9, 409-430.

Lyons, C. (1999). Definiteness. Cambridge: CUP.

MacWhinney, B. (2001). The Competition Model: the Input, the Conext, and the Brain. In: P. Robinson (ed.), Cognition and Second Language Instruction, Cambridge: Cambridge University Press, 69-90.

Oller, J. and E. Redding (1971). Article Usage and Other Language Skills. Language Learning, 21, 85-95.

Prévost, P. and L. White. (2000). Missing Surface Inflection or Impairment in Second Language Acquisition? Evidence from Tense and Agreement. Second Language Research, 16, 103-133.

Ringbom, H. (1985). The Influence of Swedish on the English of Finnish Learners. In: H. Ringbom (ed.), Foreign Language Learning and Bilingualism, Åbo: Åbo Akademi, 39-71.

Roberts, C. (2003). Uniqueness in Definite Noun Phrases. Linguistics and Philosophy, 26, 287-350.

Robertson, D. (2000). Variability in the Use of the English Article System by Chinese Learners of English. Second Language Research, 16, 13-172.

Russell, B. (1905). On Denoting. Mind, 14, 479-93.

Strawson, P. F. (1950). On Referring. Mind, 9, 320-344. 
Thomas, M. (1989). The Acquisition of English Articles by First and Secondlanguage Learners. Applied Psycholinguistics, 10, 335-355.

Trenkic, D. (2007). Variability in L2 Article Production: Beyond the Representational Deficit vs. Processing Constraints Debate. Second Language Research, 23, 289-327.

\section{Appendix}

\section{Category 1}

1. We went to a wedding last week. The bride wore blue.

2. They've just returned from New York. The plane was five hours late.

3. I hated that book. The author is an idiot.

4. [Woman] I was cleaning the house the other day and I found a box in the attic.

5. I had to get a taxi from the station. On the way, the driver told me there was a bus strike.

6. I'd like to meet the artist who painted that, but I don't know who it is. The painting isn't signed.

7. [Man examining restaurant menu] I wonder what the salmon is like today.

8. [Customer] The meat I bought here this morning is completely spoiled! I want to talk to the owner of this store! And I want to see him right now!

9. A painting by Rembrandt was stolen from the City Museum. The police are trying to catch the thief, though he may have already left the country.

10. We had dinner in that new Italian restaurant. I had chicken and salad - both were great, but the dessert was far too sweet for my taste.

\section{Category 2}

1. Don't go in that yard, the dog will bite you

2. You'll find tea and coffee in the cabinet to the right of the window.

3. I bought a blue cup and a green cup. Unfortunately, the blue cup broke before I got home. 
4. [Man at the dinner table] Please, pass the butter.

5. This afternoon I went to the park. The sun was shining and

6. ...there wasn't a cloud in the sky.

7. I went to a video store and got a film and three video games. Then I went home and watched the film.

8. [Boy] You know, Peter had two pets, a pig and a parrot. He decided to sell one of them.

Which do you think it was? - [Girl] ... The parrot.

9. I dropped five coins and found only four of them. The missing coin is probably under the sofa.

10. Last week Grandpa went to an animal market. He found a cow and a small horse that he liked. But he didn't have enough money, so he only bought the horse.

\section{Category 3}

1. There were two sweaters and three blouses on the shelf. Mary bought a blouse.

2. Sue wants a car for her eighteenth birthday, but I don't think a car is a good idea.

I wouldn't let her drive on Saturday nights.

3. [Teacher] A man went to the jungle because he wanted to see a lion or a zebra.

He looked all over and he looked and looked... Who came running at the man?

[Child] ... A zebra.

4. [Professor] I met some students before class. A student came to see me after class as well.

5. We went to a wedding last week. A guest made a speech.

6. The pet shop had five puppies and seven kittens. Mary chose $a$ puppy.

7. Carl had dinner with three students and two professors. A student brought the wine they drank

8. Mark and Tim went to see our local football team play. They had a good time and afterwards, they met a player. He was very friendly.

9. Jim has many old records. His cousin borrowed a record from him yesterday. 
10. [Woman pointing to a pile of books] John, can you see those books lying on the floor? I need a hard surface to write on. Would you please hand me a book?

Received: 15 July, 2011

Accepted for publication: 15 October, 2011

Лех Забор

\author{
ПЕРЦЕПЦИЈА ЈЕДИНСТВЕНОСТИ И УСВАЈАҢЕ ЕНГЛЕСКОГ \\ СИСТЕМА ЧЛАНОВА
}

\begin{abstract}
Сажетак
У раду се испитују обрасци употребе чланова код пољских ученика енглеског као другог језика. На основу постојећих теорија значења енглеских чланова, у раду се показује да усвајање енглеског система чланова зависи од перцепције јединствености именичке синтагме од стране ученика. Циљ рада је да се упореде одговори ученика на тесту са задацима принудног избора за три категорије именичких синтагми: (1) одређене и јединствене на основу асоцијација; (2) одређене и јединствене на основу претходног помињања, општег знања или знања о непосредној ситуацији; (3) неодређене и јединствене на основу асоцијација или претходног помињања. Анализа података добијених тестирањем две групе ученика (нижи-средњи и напредни ниво) упућује на одређене ограничене закључке у вези са улогом јединствености и других семантичких и дискурсних универзалија које кључно доприносе тумачењу енглеског одређеног члана.
\end{abstract}

Кључне речи: усвајање енглеских чланова, одређеност, јединственост 